\title{
Effects of Cultural Practices on Total Phenolics and Vitamin C Content of Organic Table Grapes
}

\author{
B. Isci $^{1}$, Z. Gokbayrak ${ }^{2 *}$, N. Keskin ${ }^{3}$ \\ (1) Department of Horticulture, Faculty of Agriculture, Ege University, İzmir, Turkey \\ (2) Department of Horticulture, Faculty of Agriculture, Canakkale Onsekiz Mart University, Canakkale, Turkey 17100 \\ (3) Department of Horticulture, Faculty of Agriculture, Yuzuncu Y1l University, Van, Turkey
}

Submitted for publication: July 2014

Accepted for publication: May 2015

Key words: Vitis, girdling, phenolics, thinning, vitamin C, HPLC, table wines

\begin{abstract}
The total phenolic and vitamin $C$ contents of organic table grapes were determined by spectrophotometry and HPLC, respectively, after several quality-increasing treatments were applied at véraison for two growing seasons. Cane girdling and cluster-berry thinning resulted in different responses in the cultivars. 'Red Globe' generally was found to produce the lowest quantity of total phenolics in the berries, while 'Trakya Ilkeren' was the cultivar that accumulated the highest phenolics. Vitamin $C$ accumulation in the berries was also affected by the treatments. The effect of the treatments was inconclusive in 'Buca Razakısı'. The application of both girdling and thinning caused more accumulation of vitamin $\mathrm{C}$ in the 'Alphonse L.' and 'Trakya Ilkeren' berries.
\end{abstract}

\section{INTRODUCTION}

There is increased awareness in the world about consuming organic food products. A vast number of published studies have dealt with comparisons of the nutritive value of agricultural products derived from both conventional and organic systems. Although there is a general consensus that organic foods contain a high dry matter and lower nitrate content (Huber et al., 2011), regarding their content of vitamins and phenolic compounds some studies have indicated that they are higher (Carbonaro et al., 2002; Wang et al., 2008) and others that they are at similar or lower levels (Lombardi-Boccia et al., 2004).

Grape berries, especially the coloured ones, contain phenolic compounds in their skins and seeds (Poudel et al., 2008). They contribute not only to colour but also to sensory properties such as the bitterness and astringency of the juice and wine. Phenolic compounds are also regarded as preservatives against microbes and the oxidation of food (Heaton, 2001; Benbrook et al., 2008). In this respect, vitamin $\mathrm{C}$ is another very important compound in the protection against oxidative stress in plants (Rock et al., 1996). It also is a co-factor of several enzymes that participate in the synthesis of anthocyanidins (Barata-Soares et al., 2004).

Table grape production usually involves treatments such as adjusting crop load by cultivar thinning and shoot topping, as well as increasing crop quality by girdling, topping or tipping, and using growth regulators, mainly gibberellic acid. The effects of these treatments on yield and quality have been studied intensely, with varying results depending on the level, time, cultivar and site.
However, there is little information on the impact of various cultural practices on the production of phenolic metabolites in organically produced table grape cultivars. This study focused on the determination of the effects of crop thinning and cane girdling on the total phenolic compounds and vitamin $\mathrm{C}$ contents of organic table grapes.

\section{MATERIALS AND METHODS}

Three coloured table grape cultivars (Vitis vinifera L.) (Alphonse Lavalleé, Red Globe and Trakya Ilkeren) and one white table grape cultivar (Buca Razakıs1) were grown organically at the experimental vineyard $\left(38^{\circ} 27^{\prime} 32^{\prime \prime} \mathrm{N}\right.$, $\left.27^{\circ} 13^{\prime} 21^{\prime \prime} \mathrm{E}\right)$ of the Department of Horticulture, Ege University, İzmir, Turkey. 'Trakya Ilkeren' is a blue-black cultivar with round and large berries. Its cluster is very large and it ripens seven to eight days before 'Cardinal'. 'Buca Razak1s1' is a white-coloured, midseason cultivar with winged conical clusters carrying 3 to $4 \mathrm{~g}$ berries. The vines grafted onto 41B rootstock were trained to a Guyot on a Y system with $2.5 \times 3 \mathrm{~m}$ spacing. The vines were seven years old at the time of the experiment. Cultivation practices and the control of pests and diseases were employed according to organic production regulations (European Council Regulation No: 834/2007). Soil conditions were as follows: sand $40 \%$, silt $40 \%$, clay $20 \%$, low salinity, pH 7.8 , organic matter $2.6 \%$.

Cluster-berry thinning (CBT) was performed at véraison, on 1 August for 'Red Globe' and 'Alphonse L.' and on 15 June for 'Trakya İlkeren' and 'Buca Razakısı'. 'Red Globe' and

*Corresponding author: E-mail address: zelihayasa@gmail.com [Tel.: +90 (286) 21800 18/1309]

Acknowledgements: The HPLC facilities of the Central Research Laboratory of the Yüzüncü Yll University 
Trakya Ilkeren' were thinned to 25 clusters per vine, while 20 clusters were retained on the other two cultivars. Clusters left on the vine were tipped to weigh approximately $500 \mathrm{~g}$. Cane girdling $(\mathrm{CG})$ was also performed at veraison on the fruiting canes just below the first basal cluster from the bottom. A $0.4 \mathrm{~cm}$ wide ring of bark was completely removed with a double-bladed knife. Control vines of each cultivar were neither thinned nor girdled. When the clusters on the control vines reached approximately $16^{\circ}$ Brix, the grapes were harvested at technological maturity and analyses were carried out. Trials were carried out during the growing seasons of 2012 and 2013.

Trials were carried out on a split-plot design in which the cultivars and the treatments were in the main and subparcels respectively. All cultivars were in the same block and replicates were planted randomly. Every treatment consisted of three replicates of four vines. At harvest, 10 clusters from each replicate of a treatment were picked and sampled for total phenolics and vitamin $\mathrm{C}$ contents. Analyses were repeated three times.

Extractions were performed by the method of Ojeda et al. (2002). For each replication, skins from 10 berries from the major class were separated manually, weighed and ground to a powder with liquid nitrogen using a porcelain mortar and pestle. Phenolic compounds were extracted into $70 \%$ acetone in water $(\mathrm{v} / \mathrm{v})$ to give an average powder concentration of $2.5 \%(\mathrm{w} / \mathrm{v})$ in $2 \mathrm{~mL}$ Eppendorf tubes. The tubes were agitated mechanically for $15 \mathrm{~min}$ at room temperature, sonicated (Bransonic 220; Roucaire, Courtaboeuf, France) for $30 \mathrm{~min}$, and centrifuged for $10 \mathrm{~min}$ at $6500 \mathrm{~g}$. The supernatant was recovered and stored at $-20^{\circ} \mathrm{C}$. Six extractions were carried out for each sample.

The total phenol content (mg/g per fresh weight) was determined by the Folin-Ciocalteu method (Singleton \& Rossi, 1965) and expressed as gallic acid equivalents (GAE) by determining the absorbance at $765 \mathrm{~nm}$. Folin-Ciocalteu reagents were purchased from Sigma Aldrich (F-9252).

The vitamin $\mathrm{C}$ content (mg per $100 \mathrm{mg}$ fresh weight) was determined by the HPLC method described by Cemeroğlu (2007), with some modifications. Whole berries were crushed and ground with a hand blender and prepared into a mesh. Three $\mathrm{g}$ was weighed and transferred to $50 \mathrm{ml}$ falcon tubes, to which $6 \mathrm{~mL}$ of $2.5 \%$ metaphosphoric acid solution was added. The mixture was centrifuged at $4^{\circ} \mathrm{C}$ and $6500 \mathrm{~g}$ for $10 \mathrm{~min}$. Clear supernatant $(2 \mathrm{~mL})$ was filtered through a $0.45 \mu \mathrm{m}$ Teflon filter. $\mathrm{A} \mathrm{C}_{18}$ column (Phenomenex Luna $\mathrm{C}_{18}, 250 \times 4.60 \mathrm{~mm}, 5 \mu$ ) was used and the column temperature was set to $25^{\circ} \mathrm{C}$. The mobile phase was ultrapure water adjusted to $\mathrm{pH} 2.2$ with $\mathrm{H}_{2} \mathrm{SO}_{4}$ at $1 \mathrm{~mL}$ per min flow rate. Readings were performed in a diode array detector at $254 \mathrm{~nm}$ wavelength using $L$-ascorbic acid (Sigma A5960) at varying concentrations (50, 100, 500, 1000,2000 ppm). Each analysis of total phenolics and vitamin $\mathrm{C}$ was repeated three times.

Because there were no significant effects of the growing seasons, the data obtained from the analyses over two growing seasons were pooled before the statistical analysis was carried out. The descriptive statistics for the studied variables (characteristics) were presented as mean and standard error. ANOVA was employed to compare for means of practices (treatments and cultivars) for the studied variables. Duncan's multiple comparison test was carried out for determination of statistically significant differences in the means. The statistical significance level considered was $5 \%$. The SPSS (SPSS Inc., IL., USA, ver. 13) statistical program was used for all computations.

\section{RESULTS AND DISCUSSION}

The statistical analysis showed that both the total phenolic and vitamin $\mathrm{C}$ contents of the cultivars were influenced by the treatments. 'Trakya Ilkeren', the earliest ripening cultivar, always had the highest amount of total phenolics $(2.09 \mathrm{mg} / \mathrm{g}$ GAE) compared to the other cultivars. The effect of a treatment on the phenolic contents changed within the cultivars. The treatment that caused a cultivar to accumulate the most phenolics compared to the others differed, such as CG+CBT in 'Trakya Ilkeren' (2.20 mg/g GAE) and 'Buca Razakısı' (1.82 mg/g GAE), CG in 'Alphonse L.' (2.00 mg/g GAE), and CBT in 'Red Globe' ( $0.84 \mathrm{mg} / \mathrm{g} \mathrm{GAE})$.

The vitamin $\mathrm{C}$ content of the cultivars showed limited variations. Mean values of the vitamin $\mathrm{C}$ accumulated in the cultivars ranged from 12.76 ('Red Globe') to 16.34 ('Alphonse L.') (Table 1). Interestingly, the control groups of both 'Buca Razakısı' and 'Alphonse L.' contained similar amounts of vitamin C. While its level in 'Buca Razakısı' did not change significantly with treatments, it showed significant variations in the 'Alphonse L.'. 'Red Globe' did not change its vitamin $\mathrm{C}$ content with the treatments. However, the 'Red Globe' vines that received both girdling and thinning accumulated less vitamin $\mathrm{C}$ in their berries. 'Alphonse L.' had a significantly lower amount of vitamin $\mathrm{C}$ in its control and thinned vines. The combined effects of girdling and thinning resulted in the highest vitamin $\mathrm{C}$ levels. Phenolic compounds and vitamin $\mathrm{C}$ are important in the production of colour and taste and in plant defence. Their content has been investigated mostly in wine grape cultivars and their wines. However, their fresh consumption in the human diet is important and also encouraged. It therefore is important to investigate these compounds in table grapes that are exposed to different treatments for increasing quantity and quality.

Varietal differences in response to the girdling and/or thinning activities in terms of total phenolic and vitamin $\mathrm{C}$ accumulation were observed in this study. Similar results have also been shown in several other studies. Kanner et al. (1994) found that three seedless table grape cultivars ('Thompson Seedless', 'Flame Seedless' and 'Black Seedless') contained 260,850 and $920 \mathrm{mg}$ per $\mathrm{kg}$ of total phenolics respectively. Cantos et al. (2002) reported varietal differences in the polyphenol profiles of seven table grape cultivars, ranging between 114.9 (cv. 'Dominga') and $361.2 \mathrm{mg}$ per $\mathrm{kg}$ fresh weight ('Flame Seedless'). Lachman et al. (2004) reported the highest phenolics in the 'Royal' table grape compared to the other must varieties studied. Proteggente et al. (2002) showed that green grape cultivars had $80 \mathrm{mg}$ total phenolics and $2 \mathrm{mg}$ vitamin $\mathrm{C}$ per $100 \mathrm{~g}$ fresh weight (FW).

Studies involving cultural practices such as girdling and generative organ thinning in table grapes are abundant. However, there are few regarding organically grown grapes. Girdling and cluster/berry thinning are two of the cultural practices that can cause an imbalance in vine nutrition and 
TABLE 1

Effects of various treatments of contents on total phenolics and vitamin $C$ of the organic table grape cultivars $( \pm$ SEM).

\begin{tabular}{|c|c|c|c|c|}
\hline & \multicolumn{4}{|c|}{ Total phenolics (mg GAE/g FW) } \\
\hline & \multicolumn{4}{|c|}{ Cultivars } \\
\hline Treatments & Alphonse L. & Red Globe & Trakya Ilkeren & Buca Razakısı \\
\hline Control & $1.71 \pm 0.01^{\mathrm{Bd}}$ & $0.78 \pm 0.01^{\mathrm{Db}}$ & $2.05 \pm 0.01^{\mathrm{Ac}}$ & $1.31 \pm 0.01^{\mathrm{Cb}}$ \\
\hline Girdling & $2.00 \pm 0.01^{\mathrm{Aa}}$ & $0.71 \pm 0.01^{\mathrm{Bc}}$ & $2.00 \pm 0.01 \mathrm{Ad}$ & $0.60 \pm 0.01^{\mathrm{Cd}}$ \\
\hline Cluster thinning & $1.77 \pm 0.01^{\mathrm{Bb}}$ & $0.84 \pm 0.01^{\mathrm{Da}}$ & $2.11 \pm 0.01^{\mathrm{Ab}}$ & $0.94 \pm 0.04^{\mathrm{Cc}}$ \\
\hline Girdling + Cluster thinning & $1.72 \pm 0.01^{\mathrm{Cc}}$ & $0.72 \pm 0.01^{\mathrm{Cc}}$ & $2.20 \pm 0+01^{\mathrm{Aa}}$ & $1.82 \pm 0.02^{\mathrm{Ba}}$ \\
\hline \multirow[t]{3}{*}{ Mean } & 1.80 & 0.76 & 2.09 & 1.17 \\
\hline & \multicolumn{4}{|c|}{ Vitamin C (mg/100 g FW) } \\
\hline & \multicolumn{4}{|c|}{ Cultivars } \\
\hline Treatments & Alphonse L. & Red Globe & Trakya Ilkeren & Buca Razakısı \\
\hline Control & $15.49 \pm 0.24^{\mathrm{Ac}}$ & $13.67 \pm 0.04^{\mathrm{Ba}}$ & $14.18 \pm 0.26^{\mathrm{Bb}}$ & $15.55 \pm 0.53^{\mathrm{Aa}}$ \\
\hline Girdling & $15.64 \pm 0.01^{\mathrm{Ac}}$ & $14.00 \pm 0.07^{\mathrm{Ba}}$ & $13.94 \pm 0.31^{\mathrm{Bb}}$ & $15.59 \pm 0.00^{\mathrm{Aa}}$ \\
\hline Cluster thinning & $16.51 \pm 0.38^{\mathrm{Ab}}$ & $12.39 \pm 0.86^{\mathrm{Bab}}$ & $15.42 \pm 0.31^{\mathrm{Aa}}$ & $16.72 \pm 0.22^{\mathrm{Aa}}$ \\
\hline Girdling+Cluster thinning & $17.70 \pm 0.04^{\mathrm{Aa}}$ & $10.99 \pm 0.05^{\mathrm{Bb}}$ & $16.21 \pm 0.19^{\mathrm{Aa}}$ & $16.21 \pm 0.91^{\mathrm{Aa}}$ \\
\hline Mean & 16.34 & 12.76 & 14.94 & 16.02 \\
\hline
\end{tabular}

*ANOVA to compare data $(\mathrm{p}=0.05)$ : Different upper cases in each row represent different cultivar means $(\mathrm{A}, \mathrm{B}, \mathrm{C}, \mathrm{D})$

Different lower cases in each column represent different treatment means (a, b, c, d). SEM: Standard error of mean

source-sink relationships. Girdling and thinning applications alone or in combination seemed to have provided more photosynthesis products to the remaining upper organs or clusters, leading to more accumulation of phenolics. Cluster thinning is reported to increase phenolic composition by changing the leaf-area-to-fruit ratio, or by hastening maturity (Prajitna et al., 2007) and to increase the anthocyanins (Guidoni et al., 2002). The coloured varieties, 'Alphonse L.', 'Red Globe' and 'Trakya Ilkeren', contained more phenolics in their berries, as expected, compared to 'Buca Razakısı', the white cultivar. Coloured grape cultivars accumulate more anthocyanins in the skin and has the highest total polyphenols (Ivanova et al., 2011). One interesting result was that 'Red Globe' had less total phenolic compounds than 'Buca Razak1sı' in all the treatments, except for the girdling alone. This is a result that conflicts with previous studies, which have reported that white varieties generally have fewer phenolic compounds than coloured varieties (Cantos et al., 2002; Lachman et al., 2004; Ivanova et al., 2011). This might have been the result of the 'Red Globe' vines being harvested before they had the chance to reach their "phenological maturity".

Organic fruit growing is considered a practice that increases the fruit's quality and composition in favour of human health. There are studies on grapes showing either a decrease or an increase in the phenolic and vitamin contents. For instance, a higher total phenolic content of organically grown wine grapes (Malusà et al., 2004) and Labrusca varieties (Dani et al., 2007) has been recorded. Dani et al. (2007) found that the juice of purple and white organic grapes contained statistically higher amounts of vitamin C. Mulero et al. (2010), in contrast, reported no changes in Monastrel grapes. However, the total phenolic contents of the cultivars studied here showed comparable results to previous studies, such as that of Kanner et al. (1994), who studied the seedless table grapes, and Revilla et al. (1995), who studied white and red grapes.

\section{CONCLUSIONS}

The response of the cultivars to the girdling and/or cluster thinning differed. Girdling and cluster thinning applied together caused white grape cultivars to accumulate more total phenolics. The quantity of vitamin $\mathrm{C}$ was more in all the cultivars except for 'Red Globe'. The empirical data, although with contradictory results, suggest that cultural practices used on grapes might influence the phenolic contents of the grapes. As consumer preferences for organic grapes increases, a better understanding and more detailed information on the effects of agricultural practices on beneficial nutrients will be required.

\section{LITERATURE CITED}

Barata-Soares, A.D., Gomez, M.L.P.A., De Mesquita, C. \& Lajolo, F.M., 2004. Ascorbic acid biosynthesis: A precursor study on plants. Braz. J. Plant Physiol. 16, 147-154.

Benbrook, C., Zhao. X., Yanez, J., Davies, N. \& Andrews, P., 2008 New evidence confirms the nutritional superiority of plant-based organic foods. State Sci. Rev. Available: http://www.organiccenter.org/reportfiles/ Nutrient_Content_SSR_Executive_Summary_Final.pdf (Accessed April 2012).

Cantos, E., Espin, J.C. \& Tomas-Barberan, F.A., 2002. Varietal differences among the polyphenol profiles of seven table grape cultivars studied by LCDAD-MS-MS. J. Agric. Food Chem. 50, 5691-5696.

Carbonaro, M., Mattera, M., Nicoli, S., Bergamo, P. \& Cappelloni, M., 2002. Modulation of antioxidant compounds in organic vs. conventional fruit (peach, Prunus persica L., and pear, Pyrus communis L.). J. Agric. Food Chem. 50, 5458-5462. 
Cemeroğlu, B., 2007. Gıda Analizleri. Gıda Teknolojisi Derneği Yayınları, pp. 168 - 171. No: 34, Ankara, Turkey [in Turkish].

Dani, C., Oliboni, L.S., Vanderlinde, R., Bonatto, D., Salvador, M. \& Henriques, J.A.P., 2007. Phenolic content and antioxidant activities of white and purple juices manufactured with organically or conventionallyproduced grapes. Food Chem. Toxicol. 45, 2574-2580.

Guidoni, S., Pierpaolo, A. \& Schubert, A., 2002. Effect of cluster thinning on berry skin anthocyanin composition of Vitis vinifera cv. Nebbiolo. Am. J. Enol. Vitic. 53, 224-226.

Heaton, S. 2001. Organic farming, food quality and human health. Soil Association Report, Bristol, UK.

Huber, M., Rembiłkowska, E., Średnicka, D., Bugel, S. \& Van De Vijver, L.P.L., 2011. Organic food and impact on human health: Assessing the status quo and prospects of research. NJAS - Wageningen J. Life Sci. 58(3-4), 103-109.

Ivanova, V., Stefova, M., Vojnoski, B., Dornyei, Á., Márk, L., Dimovska, V., Stafilov, T. \& Kilár, F., 2011. Identification of polyphenolic compounds in red and white grape varieties grown in R. Macedonia and changes of their content during ripening. Food Res. Int. 44, 2851-2860.

Kanner, J., Frankel, J.E., Granitt, R., German, B. \& Kinsella, J.E., 1994. Natural antioxidants in grapes and wines. J. Agric. Food Chem. 1004(42), 64-69.

Lachman, J., Šulc, M., Hejtmánková, A., Pivec, V. \& Orsák, M., 2004. Content of polyphenolic antioxidants and trans-resveratrol in grapes of different varieties of grapevine (Vitis vinifera L.). Hort. Sci. (Prague) 31(2), 63-69.

Lombardi-Boccia, G., Lucarini, M., Lanzi, S., Aguzzi, A. \& Cappelloni, M., 2004. Nutrients and antioxidant molecules in yellow plums (Prunus domestica L.) from conventional and organic productions: a comparative study. J. Agric. Food Chem. 52, 90-94.

Malusà, E., Laurenti, E., Ghibaudi, E. \& Rolle, L., 2004. Influence of organic and conventional management on yield and composition of grape cv. 'Grignolino'. Acta Hort. (ISHS) 640, 135-141.
Mulero, J., Pardo, F. \& Zafrilla, P., 2010. Antioxidant activity and phenolic compounds in conventional and organic red grapes (var. Monastrell). CyTA - J. Food 8(3), 185-191.

Ojeda, H., Andary, C., Kraeva, E., Carbonneau, A. \& Deloire, A., 2002. Influence of pre and postverasion water deficit on anthesis and concentration of skin phenolic compounds during berry growth of Vitis vinifera cv. Shiraz. Am. J. Enol. Vitic. 53(4), 261-267.

Poudel, P.R., Tamura, H., Kataoka, I. \& Mochioka, R., 2008. Phenolic compounds and antioxidant activities of skins and seeds of five wild grapes and two hybrids native to Japan. J. Food Comp. Anal. 21, 622-625.

Prajitna, A., Dami, I.E., Steiner, T.E., Ferree, D.C., Scheerens, J.C. \& Schwartz, S.J., 2007. Influence of cluster thinning on phenolic composition, resveratrol, and antioxidant capacity in Chambourcin wines. Am. J. Enol. Vitic. 58, 346-350.

Proteggente, A.R., Pannala, A.S., Paganga, G., Buren, L.V., Wagner, E., Wiseman, S., Put, F.V.D., Dacombe, C. \& Rice-Evans, C.A., 2002. The antioxidant activity of regularly consumed fruit and vegetables reflects their phenolic and vitamin C composition. Free Radicals Res. 36(2), 217-233.

Revilla, J.M.E.E., Alonso, E. \& Kovac, V., 1995. The phenolic composition of table grapes. In: Charalambous, G. (ed.). Proc. 8th Internat. Flavor Conf., July 1994, Cos, Greece. pp. 1579-1596.

Rock, C.L., Jacob, R. \& Bowen, P.E. 1996. Update on the biological characteristics of the antioxidant micronutrients: Vitamin C, vitamin E, and the carotenoids. J. Am. Dietetic Assoc. 96(7), 693-702.

Singleton, V.L. \& Rossi, J.A., 1965. Colorimetry of total phenolics with phosphomolybdic phosphotungstic acid reagents. Am. J. Enol. Vitic. 16, 144-158.

Wang, S.Y., Chen, C.T., Sciarappa, W., Wang, C.Y. \& Camp, M.J., 2008. Fruit quality, antioxidant capacity, and flavonoid content of organically and conventionally grown blueberries. J. Agric. Food Chem. 56, 5788-5794. 